\title{
MACROECONOMIC POLICY IMPACT ON ONCOLOGY-RELATED PUBLIC EXPENDITURE IN AN EMERGING EUROPEAN MARKET - SIGNS OF EARLY RECOVERY
}

Aleksandar Dagovic ${ }^{1}$, Ana Zugic ${ }^{2}$ and Mihajlo B Jakovljevic ${ }^{3}$

${ }^{1}$ Oncology and Radiotherapy Center, Clinical Center Kragujevac, Kragujevac, Serbia

${ }^{2}$ Faculty of Medical Sciences, University of Kragujevac, Kragujevac, Serbia

${ }^{3}$ Department of Pharmacology and Toxicology, Faculty of Medical Sciences, University of Kragujevac, Kragujevac, Serbia

UTICAJ MAKROEIKONOMSKE POLITIKE NA JAVNA IZDVAJANJA ZA ONKOLOGIJU NA RASTUĆEM

EVROPSKOM TRŽIŠTU - ZNACI RANOG OPORAVKA

Aleksandar Dagović ${ }^{1}$, Ana Žugić ${ }^{2}$ i Mihajlo B Jakovljević ${ }^{3}$

${ }^{1}$ Centar za onkologiju i radioterapiju, Klinički centar Kragujevac, Kragujevac, Srbija

${ }^{2}$ Fakultet medicinskih nauka, Univerzitet u Kragujevcu, Kragujevac, Srbija

${ }^{3}$ Katedra za farmakologiju i toksikologiju, Fakultet medicinskih nauka, Univezitet u Kragujevcu, Kragujevac, Srbija

Received / Primljen: 20. 05. 2014

Accepted / Prihvaćen: 25. 06. 2014.

\section{ABSTRACT}

Healthcare financing in Serbia has faced many challenges over the past few decades. One of the most severe challenges is a global macroeconomic recession whose far-reaching consequences deserve particular attention from policymakers in cases of the most demanding major prosperity diseases, such as cancer. The objective of the study was to assess the precise cost matrix of oncology medical care and its chronological evolution during the key years of the macroeconomic recessionary period during 2010-2013.

A retrospective database of hospital discharge invoices was analysed, encompassing 37, 978 hospital admissions and 12, 505 patients during a four-year period. Insight into microeconomic patterns of consumption across groups of medical services was provided. A payer's perspective and one-year time horizon have been adopted.

Total hospital direct medical costs of cancer diagnostics and treatment in the observed tertiary care facility decreased from $€ 7,411,446$ in 2010 to $€ 5,715,884$ in 2012 and then increased to an extraordinary $€ 8,536,364$ in 2013. The costs of oncology nursing care, imaging diagnostics and radiotherapy have increased considerably while those of pharmaceuticals and surgery have decreased radically - completely transforming the resource allocation landscape of public cancer care.

The financial burden of cancer in Serbia is considerable and, unfortunately, expected to increase further in the coming years. Worldwide economic recession and consecutive domestic policy constraints of reimbursement limitations have heavily affected the affordability of cancer treatment for ordinary citizens. Promising signs of market recovery are clearly visible in 2013, which will likely improve both access and equity of medical care in Serbian oncology clinics.

Keywords: Worldwide Crisis; Recession; Cancer; Costs; Economics; Health Financing; Health Policy; Reimbursement; Hospital; Serbia

\section{SAŽETAK}

Cilj studije je analiza trendova u javnim izdvajanjima za onkolosku zdravstvenu zaštitu u godinama duboke ekonomske recesije u svetu i na Balkanu. Ostali ciljevi su utvrditi finu strukturu troškova u ovoj kliničkoj disciplini kao i eventualno prisustvo korelacije obima potrošnje na dijagnostiku i lečenje malignih neoplazmi sa makroekonomskim kretanjima i zdravstvenom politikom u Srbiji.

Primenjena je retrospektivna studija slučaja, kojom je obuhvaćen period od cetiri godine (2010-2013.) iz perspektive finansijera zdravstvene zastite i sa usvojenim vremenskim horizontom od godinu dana. Studija je izvedena na osnovu izvoda baze podataka o 37978 epizoda bolničkog lecenja i 12505 pacijenata sa klinički potvrdjenim kancerom pri regionalnom Centru za onkologiju i radioterapiju Kliničkog Centra Kragujevac.

Ukupni direktni medicinski troskovi dijangostike i lecenja kancera u posmatranom tercijernom centru su pali sa $€ 7$, 411, 446 u 2010 na €5, 715, 884 u 2012 i iznova snažno skočili na $€ 8,536,364$ u 2013. Glavni domeni troškova koji su najviše doprineli ukupnom obimu potrosnje su bili onkoloska medicinska nega, radioterapija i lekovi.

Finansijski teret kancera u Srbiji je ogroman $i$ nažalost izgledno je da ce nastaviti da raste zahvaljujući nizu činilaca poput starenja populacije, boljeg preživljavanja, naraslih očekivanja gradanstva o pravu na pristup naprednim metodama lečenja kao i dugoročno izvesnog rasta pokrivenosti stanovništva zdravstvenom zaštitom. Posebno masivni faktori su širenje dostupnosti metoda radioterapije i refundacija skupih bioloških lekova. Obećavajući znaci oporavka nacionalnog tržista će se, nadamo se, pretočiti u napore na poboljšanju pristupa $i$ priuštivosti onkološke nege običnom građaninu.

Ključne reči: Svetska ekonomska kriza; recesija; kancer; troškovi; ekonomija; finansiranje zdravstva; zdravstvena politika; refundacija; bolnice; Srbija 


\section{INTRODUCTION}

Cost-of-illness analyses of the key prosperity diseases remain rather infrequent in Eastern Europe and the Balkans region (1). Over the past decade, a few pioneering assessments were published, laying the ground for the informed decision making of local health policymakers (2). These findings reflected the workload and financial burden imposed by the diagnostics and treatment of chronic obstructive pulmonary disease, community-acquired pneumonia, alcohol dependence, diabetes mellitus, hepatitis $C$, risky pregnancies and others (3-8). Another set of contributions revealed the considerable budgetary impact of some key medical technologies, such as medical imaging (9), radiotherapy (10) and monoclonal antibodies, applied in oncology (11-12). These and further on-going efforts on domestic, local health economic estimates are essential to improve the financial efficiency of our health system (13). This claim is supported by the well-known fact that similar estimates from high-income markets are not straight- forwardly applicable to clinical settings across Eastern Europe and the Balkans due to their substantially different histories, traditions and socioeconomic milieus (14-15).

Oncological morbidity deserves a particularly high place among the leading noncommunicable prosperity diseases. The diagnostics, treatment and rehabilitation associated with cancer are commonly much more demanding in terms of medical technology use and physician consultation time and frequency compared to other major illnesses. Additionally, the clinical outcomes of these interventions are far less predictable, with illness itself resulting in a heavily reduced life expectancy, quality of life and working ability of an individual citizen. Cancer's economic burden to the community is enormous, and the issue of treatment affordability remains high on the policy agendas of even the richest countries worldwide (16). Pioneering assessments in Serbia were published only recently and confirmed the aforementioned facts evidenced elsewhere (17).

Unfortunately, both global and European cancer prevalence and incidence are increasing (18). Serbia exhibits a slightly higher incidence compared to the EU average, which remains somewhat lower compared to the European average that includes the CIS countries and the Russian Federation (19-20). Among the most frequently cited reasons for higher oncological mortality in Serbia are poverty, unhealthy lifestyles and ecological contamination due to the Chernobyl disaster and wars in Yugoslavia during the 1990s (21-22). However, throughout Eastern Europe, poor implementation of screening procedures (23) and limited affordability of some innovative treatment technologies remain powerful contributors (24).

The global macroeconomic crisis has caused severe instability among the Western Balkan economies bordering the EU (25). The recession has compromised financial sustainability within the health sector (27), and its far-reaching consequences deserve particular attention from policymakers in cases of the most demanding major prosperity diseases, such as cancer (28). The core research question of this study was the assessment of the macroeconomic recession's impact on public medical spending mediated by national policy (29). Early signs of economic recovery, which have been present in Serbia since 2013, are likely to improve access to and the affordability of medical care for patients suffering from cancer. So far, targeted biological therapy reimbursement has remained one of the hottest domestic policy issues (30).

\section{PATIENTS AND METHODS}

To address the aforementioned research question, a retrospective, bottom-up, case series study design over a one-year horizon and payer's perspective was implemented (31). The tertiary care University of Kragujevac clinic allowed selective examination of their electronic database of discharge invoices. All patients whose cancer diagnosis was confirmed by clinical, imaging, laboratory and pathohistology findings and who were admitted and treated at the regional Oncology and Radiotherapy Centre were processed. Key cost drivers and determinants of resource consumption during oncological inpatient care were identified. Personal data remained protected during the study consistent with positive legislation on biomedical research in human subjects in Serbia via anonymous handling of patient files. A fine cost matrix was produced through stratification of the Republican Health Insurance Fund (RFZO) "Blue Code Book" of all medical goods and services provided within the national health system.

The patient sample recruitment period was January 2010-December 2013 and included inhabitants of this central Serbian region. Total sample size was 12, 505 patients or 37, 978 hospital admissions with assigned oncology treatment protocols during the $2010-2013$ period. These years were selected because the 2010-2012 years were marked by the heavy impact of worldwide economic crisis, while 2013 was a year of slow but steady recovery of the national economy. To the authors' best knowledge, this sampling method and approach to longitudinal data is standard and common in the discipline of health economics (32).

\section{RESULTS}

Total hospital direct medical costs of cancer diagnostics and treatment at this tertiary university hospital fell from $€ 7$, 411, 446 in 2010 to $€ 5,715,884$ in 2012 and then increased to an extraordinary $€ 8,536,364$ in 2013. Costs of oncology nursing care, imaging diagnostics and radiotherapy have greatly increased while pharmaceuticals and surgery followed at a much slower pace, completely transforming the resource allocation landscape of public cancer care.

Most major service groups follow this general pattern, while pharmaceuticals and surgery differ from the dominant trend. Drug acquisition represented $56,4 \%$ of total 
costs in 2010 and 53, 3\% in 2012. Cytostatics and immunosuppressants experienced a particularly steep decline in value-based turnover of $55,4 \%$, decreasing from $€ 1,699$, 164 in 2010 to $€ 758,490$ in 2012. Antibiotics, antiemetics, bone marrow stimulating factors and analgesics followed the same pattern. Among the few drugs that increased during the 2010-2012 period were monoclonal antibody costs, which rose by $20,3 \%$ (from $€ 1,350,235$ in 2010 to $€ 1,624$, 245 in 2012).

Radiotherapy costs also increased during the 20102012 period by $28,1 \%$ (from $€ 416,193$ to $€ 533,303$ ), and this increase is unfortunately mostly a consequence of a higher workload produced by more frequent outpatient visits and inpatient admissions.

Decreased surgery-related costs should be attributed to the market decreases in the prices of consumables.

The radiology imaging, contrasts and films budget impact changed substantially from 3, 515, 050 RSD (€33, $319)$ in 2010 to only $1,168,519 \operatorname{RSD}(€ 10,276)$ in 2012 , which is a nearly $70 \%$ decrease. Net savings acquired this way should be attributed to the new information system installed in the diagnostic services and clinic, which has eliminated the need for traditional roentgen films in most examination techniques. The value-based turnover across major cost domains over these four years is shown in detail in Table 1.

\section{DISCUSSION}

As indicated by the data above, some service groups show a sudden and clear upward trend in 2013, while others have followed at much slower pace. Thus, the big picture of resource allocation to cancer diagnostics and treatment in large hospitals in Serbia has evolved according to the macroeconomic landscape, market circumstances and official policies of the national authorities $(13,15,29)$.

The 2010 dominance of drug acquisition costs (primarily conventional cytostatic, antiemetic, analgesic, hormonal and antibiotic drugs) is overtaken in 2013 by expanding radiotherapy, oncology nursing care and imaging diagnostics. This pattern is consistent with previously published evidence on the region stating that particularly serious budget impacts were imposed by over-utilization of high-tech radiology imaging procedures $(11,17,24)$.

Pharmaceuticals were greatly influenced by novel, expensive biological treatments, such as monoclonal antibodies (mAbs) and protease inhibitors. This pattern is only small portion of far larger changes. One recently published study analysed official annual data from the national medicines agency (ALIMS) since 2004 (33). Total public expenditure on drugs with primary oncology-related indications increased by approximately five times during the period 2004-2012. During that same decade, public consumption of mAbs increased nearly 20 times due to the aforementioned societal and market changes (12). Although it is favourable that many patients had access to these innova- tive medicines, the cost-effectiveness of many mAbs is a source of heated international debate $(34,35)$. The societal affordability of expensive biologicals and willingness to pay thresholds are rather low in Eastern Europe compared to the West $(13,15)$. Contradictions such as shortages of basic, conventional cytostatics alongside reimbursement of most expensive medicines occur frequently $(11,12)$.

The downward slope of cytostatic drug acquisition costs from 2010 to 2012 in our regional sample has an underlying cause, which is invisible in the presented data. Unfortunately, due to pharmaceutical market disturbances across Western Balkan economies, during the last quarter of 2011 and the first five months of 2012, continuous hospital supplies of these drugs were severely threatened. These disturbances were mostly caused by delayed payments from state-owned health insurance funds to major multinational manufacturers supplying the region (13, 15). One particularly sensitive issue was the lack of simple 5-fluorouracil, which is itself a quite inexpensive medicine but is an essential part of many expensive and complex treatment protocols that could not be provided for months due to this shortage. Occasional shortages of cytostatic medicines also occurred. Consequently, clinics have experienced sudden decreases in their need for drugs used to treat the most common adverse effects of cytostatics, such as antibiotics, bone marrow growth factors and antiemetics used to treat febrile neutropenia, opportune infections and vomiting (36-38).

Another core influence of the sudden decrease in prescribing and dispensing of cytostatic drugs and their costs is the restrictive reimbursement policy imposed by the Republican Health Insurance Fund of Serbia (RHIFS), which was mostly triggered by the macroeconomic recession (39). The common practice is financial coverage of a particular medicine for select indications, such as narrowly defined malignant tumour clinical types, grades and stages, while the same drug might not be funded for another malignancy. Policies of funding agencies to prioritize interventions within their optimal clinical efficiency and cost-effectiveness were in place in many major markets around the globe (40-41).

The temporary decrease in oncology nursing care costs from 2010 to 2012 occurred immediately following domestic policy measures to allow contracted general practitioners to prescribe and administer opioid analgesics were implemented. This practice was uncommon within the national health system of Serbia. At approximately the same time, an outpatient pain treatment service was founded within this tertiary university clinic. Both measures ultimately resulted in less frequent hospital admissions due to severe metastatic pain, and patients used the opportunity to resolve their symptoms on an outpatient basis and preferred staying at home. That this strategy induces net savings while improving patient satisfaction and quality of life has already been observed elsewhere (42). The financial sustainability of home care in Serbia was recently an objective of thorough consideration (43). 
Table 1. Cost matrix of oncology related diagnostics and treatment within tertiary university clinic of Kragujevac 2010-2013

COST DOMAIN

2010

2011

2012

Number of patients diagnosed with confirmed malignancy

Number of hospital admissions due to cancer

\section{Oncology related medical care}

\begin{tabular}{|c|c|c|c|c|}
\hline Hospital Admission & $1,118,074$ & $1,102,027$ & 950,470 & 988,679 \\
\hline Physician Consultations & 50,800 & 63,924 & 42,386 & 215,942 \\
\hline Clinical Pharmacology/ Pharmacist services & 27 & 309 & 115 & \\
\hline Rehabilitation services & 355 & 2,408 & 1,462 & 1,153 \\
\hline Dialysis & 868 & 493 & 373 & 754 \\
\hline Psychotherapy & 83 & 12 & 8 & 709 \\
\hline Administrative expenses & 138 & 154 & 135 & 295 \\
\hline All Other services (social care, transport, counselling, epidemiological & 4,183 & 1,448 & 2,847 & 442,627 \\
\hline Total Cost of General - Oncology related medical care & $1,174,533$ & $1,170,776$ & 997,796 & $1,650,161$ \\
\hline \multicolumn{5}{|l|}{ Pharmaceuticals } \\
\hline Antineoplastic agents and immunosuppresants & $1,691,948$ & $1,200,255$ & 758,490 & 572,908 \\
\hline Monoclonal antibodies & $1,344,501$ & $1,432,796$ & $1,624,245$ & $1,559,090$ \\
\hline Analgesics NSAID, opioid, others - pain control medicines & 14,268 & 10,891 & 7,587 & 6,000 \\
\hline Antibiotics, antimicotics, antiviral and antiprotozoal drugs & 170,376 & 111,822 & 78,586 & 104,546 \\
\hline Antiemetics & 190,435 & 138,018 & 100,743 & 110,606 \\
\hline Parenteral and enteral nutritive solutions and systems & 118,386 & 92,833 & 86,628 & 91,349 \\
\hline Hematopoietic colony stimulating factors & 150,539 & 79,288 & 65,552 & 101,069 \\
\hline Antiandrogens, antiestrogens - therapy of steroid dependent carcinoma & 153 & 10 & & \\
\hline Blood and its derivatives - transfusions & 155,917 & 111,031 & 109,201 & 60,997 \\
\hline All other drugs & 345,498 & 306,273 & 218,122 & 264,412 \\
\hline Total cost for pharmaceuticals & $4,182,025$ & $3,483,217$ & $3,049,154$ & $2,870,977$ \\
\hline \multicolumn{5}{|l|}{ Laboratory Analysis } \\
\hline Classical Biochemistry and hemathology & 296,599 & 295,276 & 190,453 & 291,817 \\
\hline Targeted cancer prevention screenings & 71 & 83 & 13 & 1,576 \\
\hline Tumor marker detection & & & 1,010 & 2,042 \\
\hline Pathohistology tests and cytology examinations & 125,808 & 131,191 & 105,862 & 119,742 \\
\hline Immunodiagnostics, genetics, cell culture techniques & 77,689 & 66,720 & 51,570 & 73,677 \\
\hline Law medicine and forensic services & 15,217 & 16,586 & 16,125 & 31,043 \\
\hline Total cost for laboratory analysis & 515385 & 509,856 & 365,033 & 519,897 \\
\hline \multicolumn{5}{|l|}{ Surgery } \\
\hline Surgical Interventions & 132,278 & 157,041 & 135,291 & 133,586 \\
\hline Nursing care and consumables & 450,585 & 327,310 & 179,865 & 174,116 \\
\hline Total cost for surgery & 582,863 & 484,351 & 315,156 & 307,702 \\
\hline \multicolumn{5}{|l|}{ Imaging diagnostics } \\
\hline Classical imaging diagnostics - Röntgen & 5,764 & 6,177 & 4,568 & 6,498 \\
\hline Contrasts, films and consumables intended for imaging diagnostics services & 33,177 & 30,512 & 10,276 & 15,783 \\
\hline Ultrasound imaging examinations & 6,577 & 7,369 & 7,295 & 9,032 \\
\hline Imaging diagnostics & 221,555 & 231,005 & 174,272 & 358,947 \\
\hline Magnet resonance imaging & 15,795 & 9,482 & 9,685 & 28,378 \\
\hline Nuclear medicine diagnostics and treatment & 220,422 & 201,841 & 210,978 & 353,428 \\
\hline Total cost of imaging diagnostics & 503,290 & 486,386 & 417,074 & 772,066 \\
\hline \multicolumn{5}{|l|}{ Interventional radiology } \\
\hline Interventional neuroradiology services (both diagnostic and treatment) & 1,055 & 837 & 1,902 & 2,378 \\
\hline Cardial interventional radiology & 1,476 & 3,241 & 3,222 & 3,296 \\
\hline Urological interventional radiology & 2,621 & 1,474 & 948 & 2,005 \\
\hline Vascular interventional radiology & 1,160 & 571 & 151 & 357 \\
\hline Interventional radiology -other methods (biopsies, cyst punctuations, nonvascular int. etc ) & 206 & 356 & 13 & 366 \\
\hline Implants and consumables used in interventional radiology services (stents, tools etc) & 32,407 & 35,032 & 32,131 & 44,944 \\
\hline Total cost of interventional radiology & 38,925 & 41,511 & 38,367 & 53,346 \\
\hline \multicolumn{5}{|l|}{ Radiation treatment } \\
\hline Teleradiotherapy procedures in Oncology & 393,010 & 406,776 & 440,524 & $1,544,853$ \\
\hline Brachyradiotherapy (intracavitary) procedures in Oncology & 21,416 & 139,496 & 92,779 & 817,362 \\
\hline Total cost of radiation treatment & 414,425 & 546,272 & 533,303 & $2,362,215$ \\
\hline Total hospital cost (RSD) & $785,227,937$ & $703,434,811$ & $650,000,662$ & $978,626,707$ \\
\hline Total hospital cost per patient $(€)$ & 2,087 & 1,640 & 1,547 & \\
\hline Total hospital cost $(€)$ & $7,411,447$ & $6,722,370$ & $5,715,884$ & $8,536,364$ \\
\hline
\end{tabular}


Regardless of the weaknesses of these assessments in the field, it is crucial for policymakers to notice the enormous size and structure of public health expenditures on hospital in- and outpatient cancer care peculiar to the local setting $(9-12,17)$. Serbia will likely suffer from ongoing economic difficulties, such as increasing foreign debt, currency devaluation, high unemployment rates and inefficient healthcare financing $(13,15)$. A bold step forward was the introduction of national health accounts in the country based on similar World Health Organization practices in other regions across the globe (44). National health accounts (NHA) allow more precise knowledge of financial flows within the health system and international comparability of data (45). Economic and/or managerial inefficiency recognized via the NHA system might be selectively improved without affecting the availability or quality of services elsewhere in the system (46).

The most effective strategy to cope with the increasing burden of malignancies would likely be investment in population health education targeted to change risky health behaviours (47). Another rewarding investment is broad screening strategies whose cost-effectiveness has been well established in other countries (23). These strategies are particularly fruitful in some of the most prevalent carcinomas, which are curable by simple surgeries if discovered at early stages of clinical evolution (48). The early discovery of malignancies such as cervical, breast, colorectal, skin and gastric carcinomas prevents serious, expensive morbidities $(49,50)$. The outcomes and success of late treatment of advance disease forms, including surgery, complimentary radiotherapy, cytostatic protocols and occasionally novel biologicals, are highly unpredictable (24). Life expectancy is usually low, and premature mortality has enormous ethical and economic consequences for the community. Unfortunately, we are losing not only elderly citizens but also many people in their productive life stages (51).

Radiation treatments are major contributors to the total costs of care (9-10). Insufficient equipment capacities are common across the region $(13,15)$. Due to a poor network of facilities across rural and remote regions of the Balkans and difficulty accessing specialist care, many patients seek treatment too late (24). Late treatment involves multiple radiotherapy sessions with modest or poor success (52). Providing palliative, end of life care for advanced stage, metastatic disease is a more frequent practice compared to Western European and high-income settings (53). Absenteeism, decreased working ability and premature death are common (54-56).

It is crucial to emphasize that the aforementioned decreased cost of pharmaceuticals is not due to a decrease in the underlying prevalence and incidence of cancer or to successful public policy (17). Such savings are unfortunately largely a consequence of reimbursement limitations imposed by the national health insurance fund due to the macroeconomic recession $(12,13,15)$. The considerable growth of overall resource use in oncology clinical care in 2013 may be a promising early sign of economic recovery (57).

\section{Study limitations}

Although representing a pioneering attempt in the field, which is essential for Western Balkan health policymakers, the study weakness slightly limit the generalizability generalisability of the conclusions. No indirect, absenteeismrelated costs were calculated in this trial. If Grossman's human capital method was used, lost productivity, home care and premature mortality costs would likely nearly double current assessments $(51,58)$.

The retrospective approach used in this study was inevitable to acquire a large sample (31). Patient data on resource use (physician consultations, laboratory and imaging examinations, interventional radiology methods, surgical interventions, pharmaceuticals treatment, etc.) were acquired from clinical files. Therefore, important data on patients' clinical background was lacking. These are more likely to be provided within a prospective framework, which would assume much smaller sample (59). Further research should focus on the clinical outcomes of cancer treatment and assessment of cost-effectiveness, especially of medical technologies (60). This was primarily a cost of illness and budget impact estimate, and such efforts were well outside the scope and budget of this study.

\section{CONCLUSION}

Serbian public health expenditure on cancer was severely constrained by the reimbursement limitations imposed by authorities due to national consequences of the global economic recession. Slow but steady recovery is clearly visible according to the large increase in oncology related public expenditure in 2013, which was evidenced in a large domestic tertiary care university clinic. Under the assumption that GDP growth accelerates to pre-recession levels, policymakers should dedicate sufficient attention to improving the affordability and timely delivery of medical care to patients suffering from cancer. This is a key issue in a country with sizeable private outof-pocket spending on healthcare. Properly targeted screening as well as efficient and accessible diagnostic and treatment services would likely achieve better clinical outcomes, such as improved patient longevity and quality of life. Health gains by citizens in need will provide a return on investment to society by enhancing national economic productivity.

Acknowledgements - The Ministry of Science and Education of the Republic of Serbia has partially financed this study through Grant $N^{\circ} 175014$.

\section{REFERENCES}

1. Kim K, Hernlund E, Hernadi Z, Révész J, Pete I, Szánthó $\mathrm{M}$, et al. Treatment patterns, health care utilization, and costs of ovarian cancer in Central and Eastern Europe using a Delphi panel based on a retrospective chart review. Int J Gynecol Cancer 2013; 23(5):823-32. 
2. André N, Banavali, S, Snihur Y, Pasquier E. Has the time come for metronomics in low-income and middleincome countries? The Lancet Oncology 2013;14(6), e239-48.

3. Lazić Z, Gajović O, Tanasković I, Milovanović D, Atanasijević D, Jakovljević, M. GOLD Stage Impact on COPD Direct Medical Costs in Elderly. Journal of Health Behavior and Public Health 2012; 2(3):1-7.

4. Cupurdija, V., Lazic, Z., Petrovic, M., Mojsilovic, S., Cekerevac, I., Rancic, N., \& Jakovljevic, M. (2015). Community-acquired pneumonia: economics of inpatient medical care vis-à-vis clinical severity*, *. J Bras Pneumol, 41(1), 48-57.

5. Jovanović M, Jakovljević M. Inpatient detoxification procedure and facilities: financing considerations from an Eastern European perspective. Alcohol and Alcoholism 2011; 46(3):364-5.

6. Biorac N, Jakovljević $M$, Stefanović D, Perović S, Janković S. Assessment of diabetes mellitus type 2 treatment costs in the Republic of Serbia. Vojnosanit Pregl 2009; 66(4):271-6.

7. Jakovljević M, Mijailović Z, Jovičić BP, Čanović P, Gajović O, Jovanović et al.. Assessment of viral genotype impact to the cost-effectiveness and overall costs of care for PEG-interferon- $2 \alpha+$ ribavirine treated chronic hepatitis C patients. Hepat Mon 2013;19:13(6):e6750.

8. Jakovljević M, Varjačić M, Janković SM. Cost-effectiveness of ritodrine and fenoterol for treatment of preterm labor in a low-middle-income country: a case study. Value Health 2008;11(2):149-53.

9. Ranković A, Rančić N, Jovanovic M, Ivanovic M, Gajovic $\mathrm{O}$, Lazic $\mathrm{Z}$. et al. Impact of imaging diagnostics on the budget - Are we spending too much? Vojnosanit Pregl 2013; 70(7): 709-11.

10. Jakovljević $M$, Ranković A, Rancic N, Jovanović $M$, Ivanović M, Gajović O, et al. Radiology Services Costs and Utilization Patterns estimates in Southeastern Europe - A Retrospective Analysis from Serbia. Value in Health Regional Issues CEEWAA 2013;10.1016/j. vhri.2013.07.002.

11. Jakovljevic, M., Gutzwiller, F., Schwenkglenks, M., Milovanovic, O., Rancic, N., Varjacic, M., ... \& MatterWalstra, K. (2014). Costs differences among monoclonal antibodies-based first-line oncology cancer protocols for breast cancer, colorectal carcinoma and non-Hodgkin's lymphoma. JBUON, 19(3), 1111-1120.

12. Jakovljević MB. Oncology monoclonal antibodies expenditure trends and reimbursement projections in the emerging Balkan market. Farmeconomia. Health economics and therapeutic pathways 2014;15(1):27-32.

13. Jakovljević M., Jovanović M, LazićZ, Jakovljević V, Đukić A, Veličković R et al. Current efforts and proposals to reduce healthcare costs in Serbia. Serbian Journal of Experimental and Clinical Research 2011;12(4):161-3.

14. Kaló Z, Landa K, Doležal T, Vokó Z. Transferability of National Institute for Health and Clinical Excellence recommendations for pharmaceutical therapies in on- cology to Central-Eastern European countries. Eur J Cancer Care 2012; 21(4): 442-9.

15. Jakovljević MB. Resource allocation strategies in Southeastern European health policy. Eur J Health Economics: HEPAC: health economics in prevention and care. 2013; 14(2):153-9.

16. Malik NN. Controlling the cost of innovative cancer therapeutics. Nature reviews. Clinical Oncology 2009;6(9):550-2.

17. Radovanović A, Dagović A, Jakovljević M. Economics of cancer related medical care: estimates worldwide and available domestic evidence. Archive of Oncology, 2011:19(3-4):59-63.

18. Nanda A, Nossikov A, Prokhorskas R, Shabanah MH Health in the central and eastern countries of the WHO European Region: an overview. World health statistics quarterly. Rapport trimestriel de statistiques sanitaires mondiales 1993; 46(3):158-65.

19. Institute of public health of Serbia "Dr Milan Jovanovic Batut". Department for Prevention and Control of Noncommunicable Diseases. Cancer incidence and mortality in central Serbia, Report No. XII (2012). http:// www.batut.org.rs/download/publikacije/Registar\%20 za\%20rak\%20u\%20Centralnoj\%20Srbiji\%202010.pdf (Accessed 30 August 2013)

20. Institute of Public Health of Serbia, Belgrade "Dr Milan Jovanovic Batut" Health Statistical Yearbook of Republic of Serbia 2011. http://www.batut.org.rs/ download/publikacije/pub2011.pdf(2012). (Accessed 30 August 2013)

21. Chiesa F, Tradati N, Calabrese L, Gibelli B, Giugliano G, Paganelli G, et al. Thyroid disease in northern Italian children born around the time of the Chernobyl nuclear accident. Ann Oncol 2004; 15(12):1842-6.

22. Papathanasiou K, Gianoulis C, Tolikas A, Dovas D, Koutsos J, Fragkedakis N, et al. Effect of depleted uranium weapons used in the Balkan war on the incidence of cervical intraepithelial neoplasia (CIN) and invasive cancer of the cervix in Greece. Clinical and Experimental Obstetrics \& Gynecology 2005;32(1):58-60.

23. Obradović M, Mrhar A, Kos M. Cost-effectiveness analysis of HPV vaccination alongside cervical cancer screening programme in Slovenia. European journal of public health 2010; 20(4): 415-21.

24. Kovacevic A, Dragojevic-Simic V, Rancic N, Jurisevic M, Gutzwiller F, Matter-Walstra K, Jakovljevic M, Endof-life costs of medical care for advanced stage cancer patients, Vojnosanit Pregl 2015; 72(4): 1-10.

25 . Bechev D. The Periphery of the periphery: the Western Balkans and the Euro Crisis. European Council on Foreign Relations, 2012.

26. Panagiotou, Ritsa A. Effects of the global economic crisis on South-east Europe. Journal of Balkan and Near Eastern Studies 2010;12:187-94.

27. Stuckler, D., Basu, S., Suhrcke, M., Coutts, A., \& McKee, M. (2009). The public health effect of economic crises and alternative policy responses in Europe: an empiri- 
cal analysis. The Lancet, 374(9686), 315-323. Mazza R, Lina M, De Marco C, Pozzi P, Boffi R. Prevention and cancer care in Italy at the time of the world economic crisis. Epidemiol Prev 2013;37(4-5):193

28. Jakovljevic M, Vukovic M, Antunović, M, Veličković R, Siladji Djendji A, Janković, et al.( Do policy measures impact cost consciousness of healthcare professionals? Value in Health 2013; 16(7): A542.

29. Kentikelenis, A., Karanikolos, M., Papanicolas, I., Basu, S., McKee, M., \& Stuckler, D. (2011). Health effects of financial crisis: omens of a Greek tragedy. The Lancet, 378(9801), 1457-1458.

30. Jakovljevic MB, Targeted immunotherapies overtaking emerging oncology market value based growth, forthcoming JBUON 2015; 20(1): 348-353 .

31. Motheral, B., Brooks, J., Clark, M.A., Crown, W.H., Davey, et al. A checklist for retrospective database studies-report of the ISPOR Task Force on Retrospective Databases. Value in health. Journal of the International Society for Pharmacoeconomics and Outcomes Research 2003; 6(2):90-7.

32. Puder KL, Wood LL, Sherrill A. Health economics with retrospective data: selection bias issues. The Journal of international medical research 1997; 25(1): 45-51.

33. Medicines and Medicals Devices Agency of Serbia. Preparation of Professional Publications of the Agency. Belgrade, 2014. Available at: http://www.alims.gov.rs/eng/ about-agency/publication/ (last accessed February 2014).

34. Wild F. Increases in pharmaceutical expenditures of PHI by monoclonal antibodies. Versicherungsmedizin 2013; 65(2), 91-3.

35. Jakovljević MB, Nakazono S, Ogura S. Contemporary generic market in Japan - key conditions to successful evolution. Expert Rev Pharmacoecon Outcomes Res Expert Rev Pharmacoecon Outcomes Res. 2014 Apr;14(2):181-94.

36. Witteveen PO, van Groenestijn MA, Blijham GH, Schrijvers AJ. Use of resources and costs of palliative care with parenteral fluids and analgesics in the home setting for patients with end-stage cancer. Ann Oncol 1999; 10(2):161-5.

37. Kovačević A, Tarabar D, Jakovljević M, DragojevićSimić V. Colorectal carcinoma chemotherapy: current status and future directions, Pharmaca Serbica 2011;3(3-4):20-5.

38. Viale PH, Grande C, Moore S. Efficacy and cost: avoiding undertreatment of chemotherapy-induced nausea and vomiting. Clinical journal of oncology nursing, 2012;16(4):e133-141.

39. The Republic Fund of Health Insurance. Republic of Serbia. http://www.eng.rfzo.rs Accessed 30 August 2013.

40. Kolodziej M, Hoverman JR. Value-based reimbursement in oncology. Am J Manag Care 2012;18(3 Spec No.):SP124-6.

41. Ward JC. Oncology reimbursement in the era of personalized medicine and big data. J Oncol Pract. 2014;10(2):83-6.
42. Tanneberger S, Pannuti F, Mirri R, Panetta A, Mariano P, Giordani S, et al. Home hospital for advanced stage cancer patients: costs and benefits. Zeitschrift für ärztliche Fortbildung und Qualitätssicherung 1997; 91(2):117-23.

43. Konstantinović D, Lazarević V, Milovanović V, Lapcević M, Konstantinović V, Vuković M. Financial sustainability of home care in the health system of the Republic of Serbia. Srp Arh Celok Lek 2013;141(3-4):214-8.

44. Gajić-Stevanović $M$, Teodorović N, Dimitrijević S, Jovanović D. Assessment of financial flow in the health system of Serbia in a period 2003-2006. Vojnosanit Pregl. 2010;67(5):397-402.

45. World Health Organization. Guide to producing national health accounts: with special applications for low-income and middle-income countries. 2003.

46. Berman P. A. National health accounts in developing countries: appropriate methods and recent applications. Health Economics 1997; 6(1), 11-30.

47. Yamada, T., Chen, C. C., Yamada, T., Fahs, M., \& Fukawa, T. (2006). Behavioral analysis of the choice of community-based formal home care, informal home care and nursing home care in Japan. The Geneva Papers on Risk and Insurance-Issues and Practice, 31(4), 600-632.

48. Barfar E, Rashidian A, Hosseini H, Nosratnejad S, Barooti E, Zendehdel K.Cost-effectiveness of mammography screening for breast cancer in a low socioeconomic group of Iranian women. Arch Iran Med. 2014;17(4):241-5.

49. Taplin SH, Barlow W, Urban N, Mandelson MT, Timlin DJ, Ichikawa L. Stage, age, comorbidity, and direct costs of colon, prostate, and breast cancer care. J Natl Cancer Inst 1995; 87(6): 417-26.

50. Zavras A, Andreopoulos N, Katsikeris N, Zavras D, Cartsos V, Vamvakidis A. Oral cancer treatment costs in Greece and the effect of advanced disease. BMC Public Health 2002;2:12

51. Macioch T, Hermanowski T. The indirect costs of cancer-related absenteeism in the workplace in Poland. Journal of occupational and environmental medicine 2011; 53(12):1472-7.

52. Macklis R, Lasher J. Palliative radiotherapy for skeletal metastases: cost-substitution analyses and economic impact. J Oncol Manag 1999;8(2):17-22.

53. Larkin PJ, Dierckx de Casterlé B, Schotsmans P. Transition towards end of life in palliative care: an exploration of its meaning for advanced cancer patients in Europe. J Palliat Care 2007;23(2):69-79.

54. Jakovljevic M, Zugic A, Rankovic A, Dagovic A. Radiation Therapy Remains The Key Cost Driver Of Oncology Inpatient Treatment. J Med Econ. 2014 Sep 30:115. doi:10.3111/13696998.2014.971162.

55. Barton MB, Gebski V, Manderson C, Langlands AO. Radiation therapy: are we getting value for money? Clinical oncology (Royal College of Radiologists (Great Britain1995; 7(5): 287-92. 
56. Van Loon J, Grutters J, Macbeth F. Evaluation of novel radiotherapy technologies: what evidence is needed to assess their clinical and cost effectiveness, and how should we get it? The Lancet Oncology 2012; 13(4): e169-77.

57. Rescigno P, Imbevaro S, Jirillo A. The economic crisis and cancer chemotherapy: the role of the oncologist. Tumori 2012; 98(4): 532-3.

58. Zweifel P. The Grossman model after 40 years. The European journal of health economics : HEPAC : health economics in prevention and care, 2012; 13(6); 677-82.
59. Husereau D, Drummond M, Petrou S, Carswell C, Moher D, Greenberg D. ISPOR Health Economic Evaluation Publication Guidelines-CHEERS Good Reporting Practices Task Force. Consolidated Health Economic Evaluation Reporting Standards (CHEERS)--explanation and elaboration: a report of the ISPOR Health Economic Evaluation Publication Guidelines Good Reporting Practices Task Force. Value Health. 2013;16(2):231-50.

60. Uyl-de Groot CA. (2006) Economic evaluation of cancer therapies: More and better studies will lead to better choices in cancer care. Eur J Cancer; 42(17), 2862-6. 